Volume: 14 Issue: 2 Year: 2017

\section{Examination of future time perception levels and time management behaviours of the students in the Faculties of Sports Sciences by certain variables}

Spor Bilimleri Fakültesinde öğrenim gören öğrencilerin gelecek zaman alg1 düzeyleri ile zaman yönetimi davranışlarının bazı değişkenlere göre değerlendirilmesi

\begin{abstract}
The aim of this study is to examine the future time perception levels and time management behaviours of students studying in the Faculties of Sports Sciences in accordance with certain variables. In line with this aim, students $(n=747)$ of the departments of Sport Management, Coaching Training, Physical Education and Sports Teaching and Recreation Expertise in Gazi, Selçuk and Muğla Universities participated voluntarily in the study. Socio-demographic information form, Future Time Perspective Scale developed by Husman and Shell (1996) and Time Management Behaviour Scale developed by Britton and Tesser (1991) were applied on the participants. The data obtained from these tools were recorded through the package program called "IBM SPSS 22". For the statistical analyses, Independent Sample $t$ test was used for comparison by sexes while One Way Anova Test was used for comparisons by age, university and department.
\end{abstract}

As a conclusion, it was determined that future time perception is related to the variable of department while time management behaviour is associated with the variables of sex, age, university and department. This finding is thought to result from the self-realization levels of the students studying in the faculties of sport

\author{
Mehmet Dalli ${ }^{1}$ \\ Aydin Pekel ${ }^{2}$
}

\section{Özet}

$\mathrm{Bu}$ çalsşmanın amac1, Spor Bilimleri Fakültelerinde öğrenim gören öğrencilerin gelecek zaman alg1 düzeyleri ile zaman yönetimi davranışlarının bazı değişkenlere göre incelenmesidir. $\mathrm{Bu}$ amaç doğrultusunda Gazi, Selçuk ve Muğla Üniversitelerinde yer alan Spor Bilimleri Fakülteleri içerindeki, Spor Yöneticiliği, Antrenörlük Eğitimi, Beden Eğitimi ve Spor Öğretmenliği ve Rekreasyon Uzmanlığ1 bölümlerinde öğrenim gören öğrenciler $(n=747)$ gönüllü olarak katılmıştır. Katılımcılara sosyodemografik bilgi formu, Husman ve Shell (1996) tarafindan geliştirilen Gelecek Zaman Algisı Ölçeği ve Britton ve Tesser (1991) tarafindan geliştirilen Zaman Yönetimi Davranış1 Ölçeği uygulanmıştır. Elde edilen veriler "IBM SPSS 22" adlı paket program ile kayıt edilmiştir. İstatistikî işlem olarak cinsiyetlerine göre karşılaştırmada Bağımsız Örneklem t testi, yaş, üniversite ve bölümlere göre karşılaştırmada ise Oneway Anova Test istatistiği uygulanmıştır.

Sonuç olarak: Gelecek zaman algisının bölüm değişkeni ile zaman yönetimi davranışının ise cinsiyet, yaş, üniversite ve bölüm değişkenleri ile ilişkili olduğu tespit edilmiştir. Bu durumun Spor Bilimleri Fakülteleri'nde öğrenim gören öğrencilerin kendilerini gerçekleştirme düzeyleri, almış oldukları teorik ve uygulama derslerinin

\footnotetext{
${ }^{1}$ Doç. Dr., Muğla Sitk1 Koçman Üniversitesi, Spor Bilimleri Fakültesi, mehmetdalli@,mu.edu.tr

${ }^{2}$ Öğretim Görevlisi, İstanbul Gelişim Üniversitesi Beden Eğitimi ve Spor Yüksekokulu, apekel@gelisim.edu.tr
} 
Dallı, M., \& Pekel, A. (2017). Spor Bilimleri Fakültesinde öğrenim gören öğrencilerin gelecek zaman alg1 düzeyleri ile zaman yönetimi davranışlarının bazı değişkenlere göre değerlendirilmesi. Journal of Human Sciences, 14(2), 1420 1434. doi: $10.14687 /$ ihs.v14i2.4447

sciences, differences in theory and practice courses they receive, commitment of the students to their responsibilities, sociological structure of the internal and external environments in which the students live and the differences in the opportunities that the students encounter.

Keywords: Future Time Perception; Time Management Behaviours; University students.

(Extended English abstract is at the end of this document) farklılı̆̆1, öğrencilerin sorumluluklarına olan bağlıllı̆̆ , yaşanılan iç ve dış çevreninin sosyolojik yapısı ve karşılaşılan firsatların farklılığından kaynaklandığı düşünülmektedir.

Anahtar Kelimeler: Gelecek Zaman Algis1; Zaman Yönetimi Davranışı; Üniversite Öğrencileri.

\section{GİRİŞ}

Toplumlarda işlerin etkili bir şekilde yürütülebilmesi için kişilerde bireysel olarak kazanılmış ortak bir zaman algısına ihtiyaç vardır; çünkü insanlar, zamana bağlı olarak günlük yaşantılarını düzenlerler (Safran M., Şimşek A., 2009).Her insanın, geleceğine yönelik belirlediği hedeflerin zamansal olarak uzaklı̆̆ birbirinden farklıdır.Bazı insanlar, on yıl sonrası için plan yaparken bazıları da sadece altı ay sonrası için plan yapmaktadır (Nuttin J., Lens W., 1985). Gelecek zaman alg1sı bireyin, yakın veya uzak gelecekteki beklentilerinin, hedeflerinin şimdiki eylemleri üzerine etkisi olarak tanımlanmaktadır (Simons J., Vansteenkiste M., Lens W., Lacante M., 2004, Avc1 S., Erden M., 2013). İnsanların günlük yaşantılarında sergiledikleri davranışlar belirli bir amaca ulaşmaya yöneliktir ve ulaşılmak istenen bu hedefler, bazen anlık ihtiyaçları karşılamaya, bazen kısa bir süre sonra ulaşılmak istenen bir beklentiye, bazen de beş yıl, on y1l gibi uzak bir zamanda gerçekleştirilmek istenen bir hayale yönelik olabilir (Avc1 S., 2008).

Zamanın kontrol edilebilinmesi zamanın nasıl kullanıldı̆̆ının çözümlenmesine bağlıdır. Zamanın değerlendirilmesine ilişkin doğru kararı vermek, herhangi bir işi verimli yapmaktan önemlidir; çünkü doğru işlerin doğru zamanda yapılması gerekmektedir. Diğer yandan yapılan işlere veya etkinliklere entelektüel boyutu katmak, etkinlikleri az çaba ile sabırla ve zevkle yapmak da önemlidir (Latif H, Fidan F, Uçkun G., 2005). Zamanı kontrol edememek, hayatı kontrol edememektir. İște bu noktada, insanların sahip oldukları zamanı nasıl daha etkili ve verimli kontrol edebileceklerine yönelik gereksinimleri "zaman yönetimi” adlı yeni bir kavramın ortaya çıkmasına neden olmuştur (Sabuncuoğlu Z., Tüz M., 2003).Zaman yönetimi, amaçlara ulaşmak, yapılan işleri denetlemek, kişinin kendi motivasyonunu yükseltmek açısından önemli görülen bir kişisel performansı geliştirme tekniğidir (Gürbüz M., Aydın AH., 2012).

Zaman yönetiminin amacı ise: Gereksiz işleri ayırarak önemli işlere zaman kazandırmayı, çalışmalarımızda verimliliği artırmayı, uzun sürede yapılan işlerin daha kısa sürede yapılması ve sınırlı zaman içinde nitelikli işlerin yapılmasıdır (Gözel E., Halat E., 2010).Üniversite yaşamındaki bireylerin ortaya koydukları hedeflere ulaşmak için gelecek zaman alg1sı ve doğru zaman yönetiminin gerekliliği yadsınamaz bir gerçektir. Eğitimde, gelecek zaman alg1sı ve 'zaman yönetiminin’ önemi burada ortaya çıkmaktadır (Karaoğlu B., 2015).Bu çalışmanın amacı, Spor Bilimleri Fakültesi'nde öğrenim gören öğrencilerin gelecek zaman alg1 düzeyleri ile zaman yönetimi davranışlarının bazı değişkenlere göre incelenmesidir. 
Dallı, M., \& Pekel, A. (2017). Spor Bilimleri Fakültesinde öğrenim gören öğrencilerin gelecek zaman alg1 düzeyleri ile zaman yönetimi davranışlarının bazı değişkenlere göre değerlendirilmesi. Journal of Human Sciences, 14(2), 14201434. doi:10.14687/ihs.v14i2.4447

\section{YÖNTEM}

$\mathrm{Bu}$ araştırmanın evrenini Gazi, Selçuk ve Muğla Sttkı Koçman Üniversiteleri; örneklemi ise bu üniversitelere bağlı spor bilimleri fakültelerinde yer alan antrenörlük eğitimi eğitimi, beden eğitimi ve spor öğretmenliği, rekreasyon uzmanlı̆̆1 ve spor yöneticiliği bölümü öğrencileri $(n=747)$ oluşturmaktadır. Öğerenciler basit tesadüfi örnekleme yöntemi ile belirlenmiş, katılımları gönüllü olarak gerçekleşmiştir.Veri toplama aracı olarak Husman ve Shell (1996) tarafindan geliştirilen, Avc1 ve Erden (2009)tarafindan Türkçe'ye uyarlanan 27 maddeden oluşan "gelecek zaman algisı ölçeği”" kullanılmıştır.Bu ölçeğin bağllık (12 madde), değer (7 madde), genişlik (5 madde) ve hız (3 madde) olmak üzere dört alt boyutu bulunmaktadır. Ölçek, "tamamen katıllyorum=5" ve "hiç katılmıorum=1" şeklinde 5 dereceli Likert tipi ölçek üzerinden değerlendirilmiştir. Ölçeğin güvenirlik katsayıları oldukça yüksek olup, bağllık boyutu 0.82 , değer boyutu 0.72 , hız boyutu 0.72 ve genişlik boyutu 0.74 olarak gerçekleşmiştir.Veri toplama aracı olarak kullanılan diğer ölçek Britton ve Tesser (1991) tarafindan geliştirilen ve Alay ve Koçak (2002)tarafindan Türkçe'ye uyarlanan 27 maddeden oluşan "zaman yönetimi davranışı ölçeği kullanılmıştır. Bu ölçek zaman planlamas1 (16 madde), zaman tutumlar1 ( 7 madde) ve zaman tuzaklar1 (4 madde) boyutlarından oluşmaktadır.Ölçek, "her zaman=5" ve "hiçbir zaman=1" şeklinde 5 dereceli Likert tipi ölçek üzerinden değerlendirilmiştir.Ölçeğin güvenirlik katsayısı 0.80 olup, bu değer ölçeğin oldukça güvenilir olduğunu göstermektedir. Boyutların güvenirlik katsayıları: zaman planlaması boyutu 0.88 , zaman tutumları boyutu 0.66 , zaman tuzakları boyutu 0.47 . olarak raporlaştırılmıştır.

İstatistiki olarak verilerin parametrik ve non-parametrik dağılımlarına bakılmıştır.Parametrik, non-parametrik eğrileri, çarpıklık-basıklık (skewness-kurtosis) değerleri verilerin parametrik dağılım gösterdiğini ortaya koymuştur.Diğer taraftan, cinsiyetlere göre karşılaştırmada Bağımsız Örneklem t testi, yaş, üniversite ve bölümlere göre karşılaştırmada ise Oneway Anova testi uygulanmıştır.

Tablo 1. Katılımcıların Sosyo- Demografik Özellikleri

\begin{tabular}{cccc}
\hline & & Frekans & Yüzde \\
\hline \multirow{2}{*}{ Cinsiyet } & Erkek & 469 & 62,8 \\
& Kadın & 278 & 37,2 \\
\hline \multirow{3}{*}{ Yaş } & Toplam & 747 & 100 \\
& $18-22$ & 323 & 43,2 \\
& $23-27$ & 209 & 28,0 \\
& $28-32$ & 112 & 15,0 \\
& 33 ve üzeri & 103 & 13,8 \\
\hline \multirow{2}{*}{ Üniversite } & Toplam & 747 & 100 \\
& Selçuk & 249 & 33,3 \\
& Gazi & 257 & 34,4 \\
& Muğla & 241 & 32,3 \\
\hline \multirow{2}{*}{ Bölüm } & Toplam & 747 & 100 \\
& Öğretmenlik & 219 & 29,3 \\
& Spor Yöneticiliği & 206 & 27,6 \\
& Antrenörlük eğitimi & 175 & 23,4 \\
& Rekreasyon & 147 & 19,7 \\
\hline
\end{tabular}

Tablo 1 incelendiğinde, çalışmaya katılan katılımcıların \%62,8'inin erkek, \%37,2'sinin kadın olduğu, \%43,2'sinin 18-22, \%28,0'1nın 23-27, \%15,0'ının 28-32 ve \%13,8'inin 33 ve üstü yaş aralığında olduğu, \%33,3’ünün Selçuk Üniversitesi, \%34,4’ünün Gazi Üniversitesi ve \%32,3’ününde Muğla Sıtkı Koçman Üniversitesi olduğu, \%29,3’ünün Öğretmenlik, \%27,6’sının Spor Yöneticiliği, \%23,4’ünün Antrenörlük eğitimi ve \%19,7’sinin Rekreasyon bölümü olduğu tespit edilmiştir. 
Dallı, M., \& Pekel, A. (2017). Spor Bilimleri Fakültesinde öğrenim gören öğrencilerin gelecek zaman alg1 düzeyleri ile zaman yönetimi davranışlarının bazı değişkenlere göre değerlendirilmesi. Journal of Human Sciences, 14(2), 14201434. doi:10.14687/ihs.v14i2.4447

\section{BULGULAR}

Tablo 2 Katılımcıların Ölçeklere Verdiği Cevapların Betimsel İstatistikleri

\begin{tabular}{cccccc}
\hline & & $\mathbf{N}$ & Min & Max & X \pm Sd \\
\hline \multirow{3}{*}{ Gelecek Zaman } & Bağlilik & 747 & 1,00 & 5,00 & $3,43 \pm 0,66$ \\
Alg1sı & Değer & 747 & 1,57 & 5,00 & $3,29 \pm 0,56$ \\
& Hiz & 747 & 1,00 & 5,00 & $3,47 \pm 0,85$ \\
& Genişlik & 747 & 1,00 & 4,80 & $3,17 \pm 0,67$ \\
& Gelecek Zaman Alg1sı Toplam & 747 & 1,60 & 4,92 & $3,89 \pm 0,48$ \\
\hline \multirow{2}{*}{ Zaman Yönetimi } & Zaman Planlamas1 & 747 & 20,00 & 80,00 & $45,75 \pm 9,67$ \\
& Zaman Tutumlar1 & 747 & 8,00 & 35,00 & $19,87 \pm 4,63$ \\
& Zaman Tuzaklar1 & 747 & 4,00 & 20,00 & $13,76 \pm 3,45$ \\
& Zaman Yönetimi Toplam & 747 & 37,00 & 120,00 & $79,38 \pm 12,81$ \\
\hline
\end{tabular}

Tablo 2 incelendiğinde; çalışmaya katılan katılımcıların, Gelecek Zaman Algısı ölçeği Bağllık

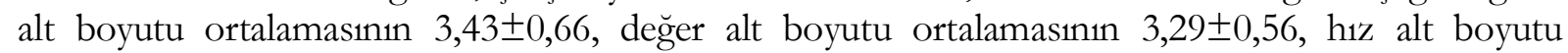

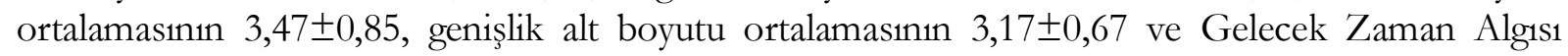
toplam puan ortalamasının 3,89 0,48 olduğu, Zaman Yönetimi ölçeği alt boyut ortalamalarına

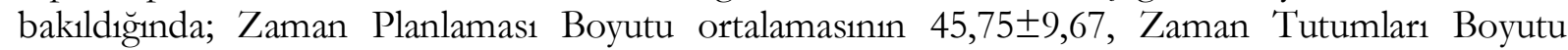

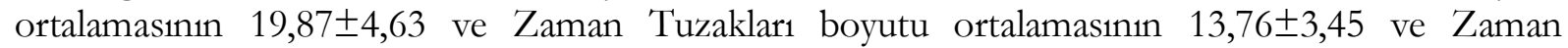
Yönetimi toplam puan ortalamasının 79,38 $\pm 12,81$ olduğu tespit edilmiştir.

Tablo 3.Katılımcıların Cinsiyetlerine Göre Gelecek Zaman Alg1 Düzeyi Analizi

\begin{tabular}{|c|c|c|c|c|c|}
\hline & Cinsiyet & $\mathbf{N}$ & $\mathrm{X} \pm \mathrm{Sd}$ & $\mathbf{t}$ & $\mathrm{p}$ \\
\hline \multirow[t]{2}{*}{ Bağlılık Boyutu } & Erkek & 469 & $3,45 \pm 0,68$ & \multirow{2}{*}{1,084} & \multirow{2}{*}{,279 } \\
\hline & Kadin & 278 & $3,40 \pm 0,64$ & & \\
\hline \multirow[t]{2}{*}{ Değer Boyutu } & Erkek & 469 & $3,29 \pm 0,57$ & \multirow{2}{*}{,346 } & \multirow{2}{*}{, 730} \\
\hline & Kadin & 278 & $3,28 \pm 0,54$ & & \\
\hline \multirow[t]{2}{*}{ Hiz Boyutu } & Erkek & 469 & $3,45 \pm 0,84$ & \multirow{2}{*}{$-1,113$} & \multirow{2}{*}{,266 } \\
\hline & Kadin & 278 & $3,52 \pm 0,85$ & & \\
\hline \multirow[t]{2}{*}{ Genişlik Boyutu } & Erkek & 469 & $3,16 \pm 0,68$ & \multirow[t]{2}{*}{,- 578} & \multirow[t]{2}{*}{,564 } \\
\hline & Kadin & 278 & $3,19 \pm 0,67$ & & \\
\hline
\end{tabular}

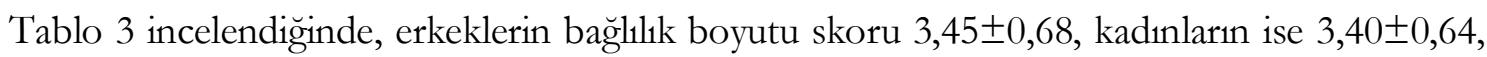
değer boyutunda erkeklerin skoru 3,29 $\pm 0,57$, kadınların ise 3,28 $\pm 0,54$, hiz boyutunda erkeklerin

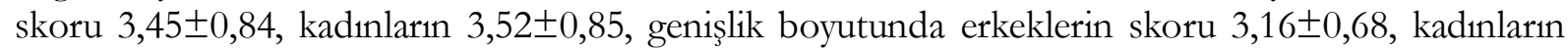
ise 3,19 $\pm 0,67$ olduğu tespit edilmiştir. Yapılan istatistikî analizler sonucunda anlamlı farklılık tespit edilmemiştir ( $p>0,05)$.

Tablo 4.Katılımcıların Cinsiyetlerine Göre Zaman Yönetimi Davranışlarının Analizi

\begin{tabular}{|c|c|c|c|c|c|}
\hline & Cinsiyet & $\mathbf{N}$ & $\mathrm{X} \pm \mathrm{Sd}$ & $\mathbf{t}$ & $\mathrm{p}$ \\
\hline \multirow{2}{*}{$\begin{array}{l}\text { Zaman } \\
\text { Planlaması }\end{array}$} & Erkek & 469 & $46,25 \pm 9,83$ & \multirow{2}{*}{1,839} & \multirow{2}{*}{, 066} \\
\hline & Kadın & 278 & $44,91 \pm 9,34$ & & \\
\hline \multicolumn{2}{|c|}{ Zaman TutumlarıErkek } & 469 & $20,21 \pm 4,61$ & \multirow{2}{*}{2,582} & \multirow{2}{*}{010} \\
\hline & Kadin & 278 & $19,31 \pm 4,61$ & & \\
\hline \multicolumn{2}{|c|}{ Zaman Tuzaklanı Erkek } & 469 & $13,38 \pm 3,59$ & \multirow{2}{*}{$-3,949$} & \multirow{2}{*}{, 000} \\
\hline & Kadin & 278 & $14,40 \pm 3,11$ & & \\
\hline
\end{tabular}


Dallı, M., \& Pekel, A. (2017). Spor Bilimleri Fakültesinde öğrenim gören öğrencilerin gelecek zaman alg1 düzeyleri ile zaman yönetimi davranışlarının bazı değişkenlere göre değerlendirilmesi. Journal of Human Sciences, 14(2), 1420 1434. doi:10.14687/ihs.v14i2.4447

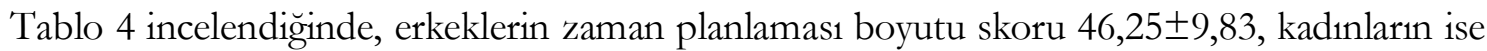

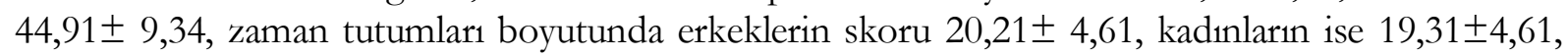

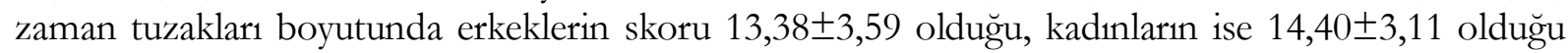
tespit edilmiştir. Yapılan istatistikî analizler sonucunda zaman tutumları boyutu ve zaman tuzakları boyutunda anlamlı farklılık tespit edilmiştir $(\mathrm{p}<0,05)$.

Tablo 5. Katılımcıların Yaş Gruplarına Göre Gelecek Zaman Alg1 Düzeyi Analizi

\begin{tabular}{|c|c|c|c|c|c|c|}
\hline & Yaş & $\mathbf{N}$ & $\mathrm{X} \pm \mathrm{Sd}$ & f & $\mathrm{p}$ & $\begin{array}{l}\text { Tukey } \\
\text { HSD }\end{array}$ \\
\hline \multirow{3}{*}{ Bağlılık Boyutu } & $18-22^{1}$ & 377 & $3,82 \pm 0,56$ & \multirow{3}{*}{, 533} & \multirow{3}{*}{, 587} & \multirow[t]{3}{*}{-} \\
\hline & $23-27^{2}$ & 233 & $3,86 \pm 0,55$ & & & \\
\hline & $28-32^{3}$ & 137 & $3,81 \pm 0,55$ & & & \\
\hline \multirow{3}{*}{ Değer Boyutu } & $18-22^{1}$ & 377 & $3,29 \pm 0,54$ & \multirow{3}{*}{143} & \multirow{3}{*}{, 867} & \multirow{3}{*}{-} \\
\hline & $23-27^{2}$ & 233 & $3,30 \pm 0,57$ & & & \\
\hline & $28-32^{3}$ & 137 & $3,27 \pm 0,58$ & & & \\
\hline \multirow{3}{*}{ Hiz Boyutu } & $18-22^{1}$ & 377 & $3,47 \pm 0,86$ & \multirow[t]{3}{*}{1,164} & \multirow[t]{3}{*}{, 313} & \multirow{3}{*}{-} \\
\hline & $23-27^{2}$ & 233 & $3,53 \pm 0,84$ & & & \\
\hline & $28-32^{3}$ & 137 & $3,39 \pm 0,83$ & & & \\
\hline \multirow{3}{*}{ Genişlik Boyutu } & $18-22^{1}$ & 377 & $3,22 \pm 0,63$ & \multirow{3}{*}{2,234} & \multirow{3}{*}{,108 } & \multirow{3}{*}{-} \\
\hline & $23-27^{2}$ & 233 & $3,15 \pm 0,69$ & & & \\
\hline & $28-32^{3}$ & 137 & $3,08 \pm 0,75$ & & & \\
\hline
\end{tabular}

Tablo 5’te, katılımcıların yaş değişkenine göre gelecek zaman alg1 düzeyleri incelendiğinde;

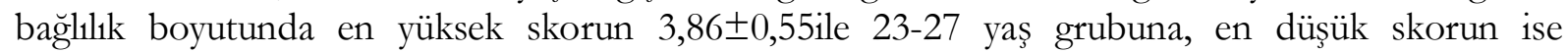
$3,81 \pm 0,55$ ile $28-32$ yaş grubuna, değer boyutu incelendiğinde; en yüksek skorun $3,30 \pm 0,57$ ile 23 27 yaş grubuna, en düşük skorun ise $3,27 \pm 0,58$ ile $28-32$ yaş grubuna, hız boyutu skoru incelendiğinde; en yüksek skorun 3,53 $\pm 0,84$ ile $23-27$ yaş grubuna, en düşük skorun ise $3,39 \pm 0,83$ ile 28-32 yaş grubuna, genişlik boyutunda en yüksek skorun 3,22 $\pm 0,63$ ile 18-22 yaş grubuna en

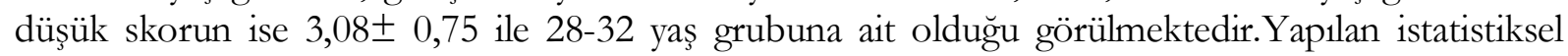
analiz sonucunda anlamlı farklılık tespit edilmemiştir ( $p>0,05)$.

Tablo 6. Katılımcıların Yaş Gruplarına Göre Zaman Yönetimi Davranışlanının Analizi

\begin{tabular}{|c|c|c|c|c|c|c|}
\hline & Yaş & $\mathbf{N}$ & $\mathrm{X} \pm \mathrm{Sd}$ & f & $\mathrm{p}$ & $\begin{array}{l}\text { Tukey } \\
\text { HSD }\end{array}$ \\
\hline \multirow{3}{*}{ Zaman Planlamas1 } & $18-22^{1}$ & 377 & $45,78 \pm 9,98$ & \multirow{3}{*}{7,781} & \multirow{3}{*}{, 000} & \multirow{3}{*}{$\begin{array}{l}1-3 \\
2-3\end{array}$} \\
\hline & $23-27^{2}$ & 233 & $47,23 \pm 9,79$ & & & \\
\hline & $28-32^{3}$ & 137 & $43,16 \pm 7,94$ & & & \\
\hline \multirow{3}{*}{ Zaman Tutumları } & $18-22^{1}$ & 377 & $20,54 \pm 4,60$ & \multirow{3}{*}{26,850} & \multirow{3}{*}{, 000} & \multirow{3}{*}{$\begin{array}{l}1-3 \\
2-3\end{array}$} \\
\hline & $23-27^{2}$ & 233 & $20,28 \pm 4,12$ & & & \\
\hline & $28-32^{3}$ & 137 & $17,35 \pm 4,71$ & & & \\
\hline \multirow{3}{*}{ Zaman Tuzakları } & $18-22^{1}$ & 377 & $13,73 \pm 3,51$ & \multirow{3}{*}{4,292} & \multirow{3}{*}{014} & \multirow{3}{*}{$2-3$} \\
\hline & $23-27^{2}$ & 233 & $13,39 \pm 3,61$ & & & \\
\hline & $28-32^{3}$ & 137 & $14,47 \pm 2,88$ & & & \\
\hline
\end{tabular}

Tablo 6'da, katıllımcıların yaş değişkenine göre zaman yönetimi davranışları incelendiğinde,

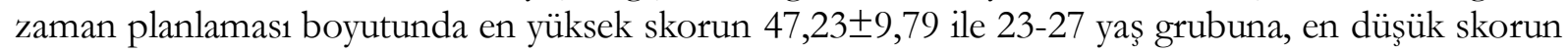
ise 43,16 $\pm 7,94$ ile 28-32 yaş grubuna, zaman tutumlar1 boyutu incelendiğinde; en yüksek skorun

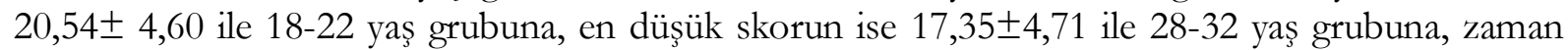

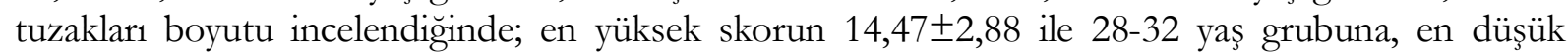


Dallı, M., \& Pekel, A. (2017). Spor Bilimleri Fakültesinde öğrenim gören öğrencilerin gelecek zaman alg1 düzeyleri ile zaman yönetimi davranışlarının bazı değişkenlere göre değerlendirilmesi. Journal of Human Sciences, 14(2), 14201434. doi:10.14687/ihs.v14i2.4447

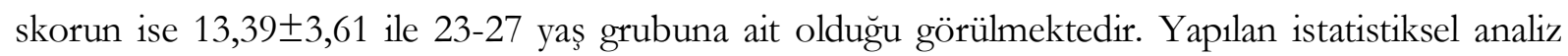
sonucunda zaman planlamas1, zaman tutumları ve zaman tuzakları boyutunda anlamlı farklilik tespit edilmiştir $(\mathrm{p}<0,05)$.

Tablo 7. Katılımcıların Üniversitelerine Göre Gelecek Zaman Alg1 Düzeyi Analizi

\begin{tabular}{|c|c|c|c|c|c|c|}
\hline & Üniversite & $\mathbf{N}$ & $\mathrm{X} \pm \mathrm{Sd}$ & $\mathrm{f}$ & $\mathrm{p}$ & $\begin{array}{l}\text { Tukey } \\
\text { HSD }\end{array}$ \\
\hline & Selçuk ${ }^{1}$ & 249 & $3,82 \pm 0,56$ & \multirow{3}{*}{828} & \multirow{3}{*}{,437 } & \multirow{3}{*}{ - } \\
\hline \multirow{2}{*}{ Bağlılık Boyutu } & Gazi $^{2}$ & 257 & $3,81 \pm 0,54$ & & & \\
\hline & Muğla 3 & 241 & $3,87 \pm 0,57$ & & & \\
\hline \multirow{3}{*}{ Değer Boyutu } & Selçuk ${ }^{1}$ & 249 & $3,29 \pm 0,57$ & \multirow{3}{*}{,423 } & \multirow{3}{*}{,655 } & \multirow{3}{*}{ - } \\
\hline & Gazi $^{2}$ & 257 & $3,26 \pm 0,52$ & & & \\
\hline & Muğla 3 & 241 & $3,31 \pm 0,58$ & & & \\
\hline \multirow{3}{*}{ Hiz Boyutu } & Selçuk 1 & 249 & $3,49 \pm 0,85$ & \multirow{3}{*}{1,413} & \multirow{3}{*}{,244 } & \multirow{3}{*}{ - } \\
\hline & Gazi $^{2}$ & 257 & $3,40 \pm 0,85$ & & & \\
\hline & Muğla & 241 & $3,53 \pm 0,84$ & & & \\
\hline \multirow{3}{*}{ Genişlik Boyutu } & Selçuk ${ }^{1}$ & 249 & $3,21 \pm 0,69$ & \multirow{3}{*}{, 533} & \multirow{3}{*}{,587 } & \multirow{3}{*}{ - } \\
\hline & Gazi $^{2}$ & 257 & $3,16 \pm 0,71$ & & & \\
\hline & Muğla ${ }^{3}$ & 241 & $3,15 \pm 0,62$ & & & \\
\hline
\end{tabular}

Tablo 7'de, katılımcıların üniversite değişkenine göre gelecek zaman alg1 düzeyleri

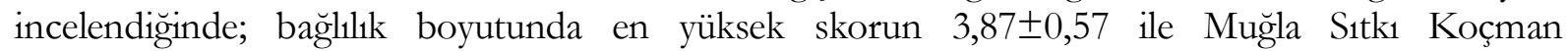
Üniversitesi, en düşük skorun ise 3,81 $\pm 0,54$ ile Gazi Üniversitesi’ne ait olduğu görülmektedir. Değer boyutu incelendiğinde, en yüksek skorun 3,31 0 ,58 ile Muğla Sttk1 Koçman Üniversitesi, en

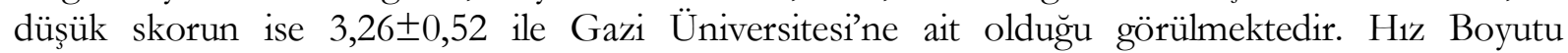

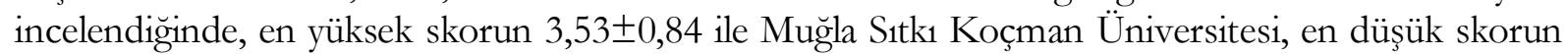

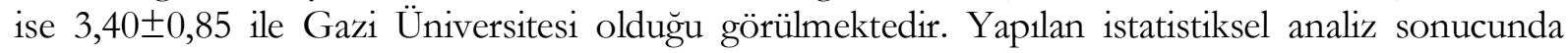
anlamlı farklılık tespit edilmemiştir.

Tablo 8. Katılımcıların Üniversitelerine Göre Zaman Yönetimi Davranışlarının Analizi

\begin{tabular}{|c|c|c|c|c|c|c|}
\hline & Üniversite & $\mathbf{N}$ & $\mathrm{X} \pm \mathrm{Sd}$ & f & $\mathrm{p}$ & $\begin{array}{l}\text { Tukey } \\
\text { HSD }\end{array}$ \\
\hline \multirow{3}{*}{ Zaman Planlaması } & Selçuk $^{1}$ & 249 & $43,59 \pm 8,60$ & \multirow{3}{*}{27,729} & \multirow{3}{*}{, 000} & \multirow{3}{*}{$1-3$} \\
\hline & $\mathrm{Gazi}^{2}$ & 257 & $44,42 \pm 8,93$ & & & \\
\hline & Muğla ${ }^{3}$ & 241 & $49,40 \pm 10,43$ & & & \\
\hline \multirow{3}{*}{ Zaman Tutumları } & Selçuk $^{1}$ & 249 & $17,80 \pm 4,29$ & \multirow{3}{*}{53,247} & \multirow{3}{*}{, 000} & \multirow{3}{*}{$\begin{array}{l}1-2 \\
1-3\end{array}$} \\
\hline & $\mathrm{Gazi}^{2}$ & 257 & $20,04 \pm 4,59$ & & & \\
\hline & Muğla ${ }^{3}$ & 241 & $21,83 \pm 4,10$ & & & \\
\hline \multirow{3}{*}{ Zaman Tuzaklan } & Selçuk $^{1}$ & 249 & $14,76 \pm 3,05$ & \multirow{3}{*}{23,599} & \multirow{3}{*}{, 000} & \multirow{3}{*}{$\begin{array}{l}1-2 \\
1-3\end{array}$} \\
\hline & $\mathrm{Gazi}^{2}$ & 257 & $12,71 \pm 3,54$ & & & \\
\hline & Muğla ${ }^{3}$ & 241 & $13,84 \pm 3,45$ & & & \\
\hline
\end{tabular}

Tablo 8'de, katılımcıların üniversite değişkenine göre zaman yönetimi davranışları incelendiğinde zaman planlaması boyutunda en yüksek skorun 49,40 $\pm 10,43$ ile Muğla Sttk1 Koçman Üniversitesi, en düşük skorun ise 43,59 $\pm 8,60$ ile Selçuk Üniversitesi'ne ait olduğu

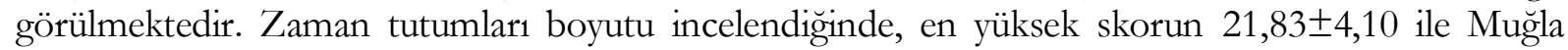

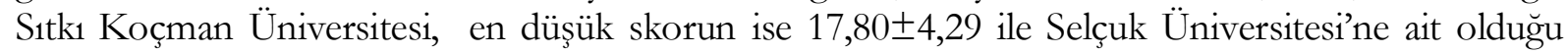
görülmektedir. Zaman tuzakları boyutu incelendiğinde; en yüksek skorun 14,76 $\pm 3,05$ ile Selçuk Üniversitesi’ne, en düşük skorun ise 12,71 $\pm 3,54$ ile Gazi Üniversitesi’ne ait olduğu görülmektedir. Yapılan istatistiksel analiz sonucunda zaman planlamas1, zaman tutumlar1 ve zaman tuzaklar1 boyutunda anlamlı farkllilk tespit edilmiştir $(\mathrm{p}<0,001)$. 
Dallı, M., \& Pekel, A. (2017). Spor Bilimleri Fakültesinde öğrenim gören öğrencilerin gelecek zaman alg1 düzeyleri ile zaman yönetimi davranışlarının bazı değişkenlere göre değerlendirilmesi. Journal of Human Sciences, 14(2), 1420 1434. doi:10.14687/ihs.v14i2.4447

Tablo 9. Katılımcıların Bölümlerine Göre Gelecek Zaman Alg1 Düzeyi Analizi

\begin{tabular}{|c|c|c|c|c|c|c|}
\hline & Bölüm & $\mathbf{N}$ & $\mathrm{X} \pm \mathrm{Sd}$ & f & $\mathrm{p}$ & $\begin{array}{l}\text { Tukey } \\
\text { HSD }\end{array}$ \\
\hline \multirow{4}{*}{ Bağlılık Boyutu } & Spor Yöneticiliği ${ }^{1}$ & 206 & $3,77 \pm 0,54$ & \multirow{4}{*}{1,572} & \multirow{4}{*}{,195 } & \multirow{4}{*}{-} \\
\hline & Antrenörlük Eğitimi² & 175 & $3,86 \pm 0,59$ & & & \\
\hline & Öğretmenlik 3 & 219 & $3,83 \pm 0,57$ & & & \\
\hline & Rekreasyon ${ }^{4}$ & 147 & $3,89 \pm 0,52$ & & & \\
\hline \multirow{4}{*}{ Değer Boyutu } & Spor Yöneticiliği1 & 206 & $3,20 \pm 0,53$ & \multirow{4}{*}{3,122} & \multirow{4}{*}{025} & \multirow{4}{*}{$1-3$} \\
\hline & Antrenörlük Eğitimi ${ }^{2}$ & 175 & $3,28 \pm 0,56$ & & & \\
\hline & Öğretmenlik ${ }^{3}$ & 219 & $3,36 \pm 0,58$ & & & \\
\hline & Rekreasyon ${ }^{4}$ & 147 & $3,32 \pm 0,54$ & & & \\
\hline \multirow{4}{*}{ Hiz Boyutu } & Spor Yöneticiliği1 & 206 & $3,43 \pm 0,88$ & \multirow{4}{*}{972} & \multirow{4}{*}{,405 } & \multirow{4}{*}{-} \\
\hline & Antrenörlük Eğitimi² & 175 & $3,56 \pm 0,80$ & & & \\
\hline & Öğretmenlik ${ }^{3}$ & 219 & $3,46 \pm 0,85$ & & & \\
\hline & Rekreasyon 4 & 147 & $3,44 \pm 0,84$ & & & \\
\hline \multirow{4}{*}{ Genişlik Boyutu } & Spor Yöneticiliği ${ }^{1}$ & 206 & $3,14 \pm 0,69$ & \multirow{4}{*}{1,673} & \multirow{4}{*}{,171 } & \multirow{4}{*}{-} \\
\hline & Antrenörlük Eğitimi² & 175 & $3,13 \pm 0,62$ & & & \\
\hline & Öğretmenlik ${ }^{3}$ & 219 & $3,26 \pm 0,69$ & & & \\
\hline & Rekreasyon ${ }^{4}$ & 147 & $3,14 \pm 0,68$ & & & \\
\hline
\end{tabular}

Tablo 9'da, katılımcıların bölüm değişkenine göre gelecek zaman alg1 düzeyleri

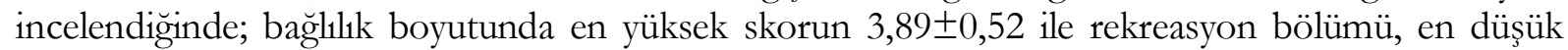
skorun ise $3,77 \pm 0,54$ ile spor yöneticiliği bölümüne ait olduğu görülmektedir. Değer boyutu incelendiğinde, en yüksek skorun $3,36 \pm 0,58$ ile beden eğitimi ve spor öğretmenliği bölümü, en düşük skorun ise $3,20 \pm 0,53$ ile spor yöneticiliği bölümüne ait olduğu görülmektedir. Hız Boyutu

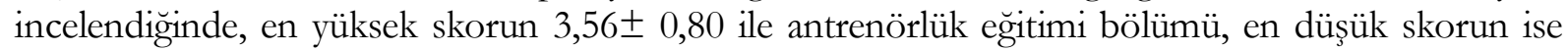
$3,43 \pm 0,88$ ile spor yöneticiliği bölümüne ait olduğu görülmektedir. Genişlik boyutunda en yüksek

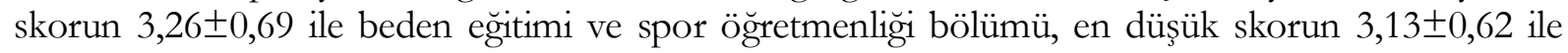
antrenörlük eğitimi bölümüne ait olduğu görülmektedir. Yapılan istatistiksel analiz sonucunda değer boyutunda anlamlı farklılık tespit edilmiştir $(\mathrm{p}<0,05)$.

Tablo 10. Katılımcıların Bölümlerine Göre Zaman Yönetimi Davranışlarının Analizi

\begin{tabular}{|c|c|c|c|c|c|c|}
\hline & Bölüm & $\mathbf{N}$ & $X \pm S d$ & f & $\mathrm{p}$ & $\begin{array}{l}\text { Tukey } \\
\text { HSD }\end{array}$ \\
\hline \multirow{4}{*}{ Zaman Planlamas1 } & Spor Yöneticiliği & 206 & $45,73 \pm 9,94$ & \multirow{4}{*}{7,537} & \multirow{4}{*}{000} & \\
\hline & Antrenörlük Eğitimi & 175 & $48,50 \pm 9,82$ & & & \\
\hline & Öğretmenlik & 219 & $43,99 \pm 8,36$ & & & $2-3$ \\
\hline & Rekreasyon & 147 & $45,13 \pm 10,26$ & & & \\
\hline \multirow{4}{*}{ Zaman Tutumları } & Spor Yöneticiliği & 206 & $19,64 \pm 4,35$ & \multirow{4}{*}{12,233} & \multirow{4}{*}{,000 } & $1-2$ \\
\hline & Antrenörlük Eğitimi & 175 & $21,47 \pm 4,36$ & & & $2-3$ \\
\hline & Öğretmenlik & 219 & $18,72 \pm 4,58$ & & & $2-4$ \\
\hline & Rekreasyon & 147 & $20,01 \pm 4,87$ & & & $3-4$ \\
\hline \multirow{4}{*}{ Zaman Tuzaklan } & Spor Yöneticiliği & 206 & $14,21 \pm 3,41$ & \multirow{4}{*}{1,830} & \multirow{4}{*}{,140 } & \multirow{4}{*}{ - } \\
\hline & Antrenörlük Eğitimi & 175 & $13,42 \pm 3,56$ & & & \\
\hline & Öğretmenlik & 219 & $13,63 \pm 3,38$ & & & \\
\hline & Rekreasyon & 147 & $13,71 \pm 3,46$ & & & \\
\hline
\end{tabular}

Tablo 10'da, katılımcıların bölüm değişkenine göre zaman yönetimi davranışları

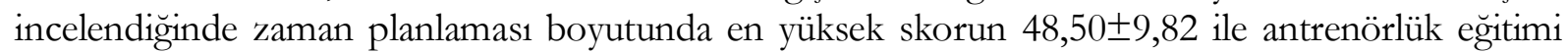

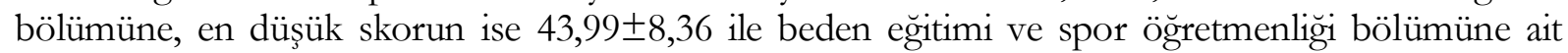

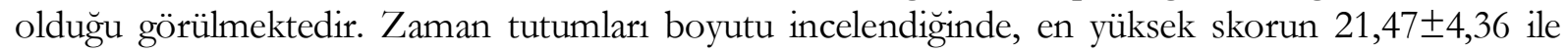

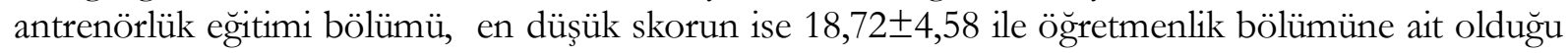
görülmektedir. Zaman tuzakları boyutu incelendiğinde; en yüksek skorun 14,21 $\pm 3,41$ ile spor

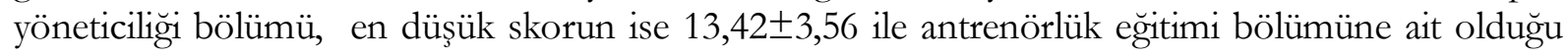


Dallı, M., \& Pekel, A. (2017). Spor Bilimleri Fakültesinde öğrenim gören öğrencilerin gelecek zaman alg1 düzeyleri ile zaman yönetimi davranışlarının bazı değişkenlere göre değerlendirilmesi. Journal of Human Sciences, 14(2), 14201434. doi:10.14687/ihs.v14i2.4447

görülmektedir. Yapılan istatistiksel analiz sonucunda zaman planlamas1 ve zaman tutumlar1 boyutunda anlamlı farkllilk tespit edilmiştir ( $\mathrm{p}<0,001)$.

\section{TARTIŞMA SONUÇ ve ÖNERİLER}

Çalışmaya katılan öğrencileringelecek zaman alg1sı ölçeği bağlllık alt boyutu ortalamasının $3,43 \pm 0,66$, değer alt boyutu ortalamasinin 3,29 $\pm 0,56$, hiz alt boyutu ortalamasinın $3,47 \pm 0,85$, genişlik alt boyutu ortalamasinin $3,17 \pm 0,67$ ve gelecek zaman algisı toplam puan ortalamasinin 3,89 0,48 olduğu görülürken; zaman yönetimi davranışı ölçeği alt boyut ortalamalarına bakıldığında, zaman planlaması boyutu ortalamasinin 45,75 $\pm 9,67$, zaman tutumları boyutu ortalamasinin $19,87 \pm 4,63$, zaman tuzaklar1 boyutu ortalamasinin $13,76 \pm 3,45$ ve zaman yönetimi toplam puan ortalamasının 79,38 $\pm 12,81$ olduğu tespit edilmiştir. Literatür incelendiğinde; gelecek zaman algis1 ile ilgili çalışmalar mevcut (Avcı S., Erden M., 2009, Avcı S., Erden M., 2013)olmasına rağmen, gelecek zaman algisı alt boyut ortalamalarının tespit edildiği herhangi bir çalısmaya rastlanılmamıştır (Karaoğlu B., 2015). Beden Eğitimi ve Spor Yüksekokulu öğrencilerinin zaman yönetimi davranışlarının incelenmesi üzerine yaptığı çalışmada; zaman planlaması boyutu puan ortalamasını 34, zaman tutumları boyutu puan ortalamasinı 24,zaman tuzakları boyutu puan ortalamasin 15 ve zaman yönetimi toplam puan ortalamasını 73 olarak tespit etmiştir (Erdul G., 2005). Üniversite öğrencilerine yapmış olduğu çalışmada; zaman yönetimi davranışı alt boyut ortalamalarını; zaman planlamas boyutu puan ortalamasin1 49.13 \pm 8.95 , zaman tutumlar1 boyutu puan ortalamasinı $22.99 \pm 3.65$, zaman tuzakları boyutu puan ortalamasını $22.99 \pm 3.26$ ve zaman yönetimi toplam puan ortalamasını 85.14 \pm 11.46 olarak tespit etmiştir.Zaman yönetimi davranış1 ölçeğinden alınabilecek toplam puan 47 ile 123 arasında değişmekte olup alınan yüksek puan katılımcıların zaman yönetimi davranışının yüksek olduğunu göstermektedir (Uyanıker EA., 2014).Zaman yönetimi davranışı ile ilgili yapılan çalışmalarda zaman yönetimi davranışı toplam puan ortalamaları çalışmamızın bulguları ile paralellik göstermektedir.Bu durumun; spor bilimleri fakültesinde öğrenim gören öğrencilerin, zamanlarını orta düzeyde verimli kullandıklarından kaynakladığ1 söylenebilinir.

Katılımciların gelecek zaman alg1sı alt boyutu skorları cinsiyete göre Tablo 3’te incelenmiştir.

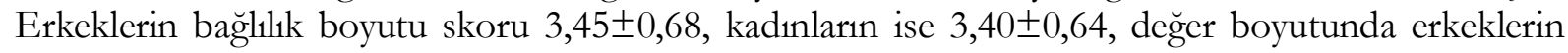
skoru $3,29 \pm 0,57$, kadınların ise 3,28 $\pm 0,54$, hı boyutunda erkeklerin skoru $3,45 \pm 0,84$, kadınların ise

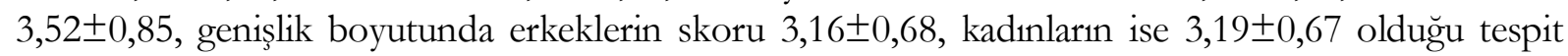
edilmiştir. Yapılan istatistikî analizler sonucunda anlamlı farklılık tespit edilmemiştir. Literatür incelendiğinde; Üstün ve arkadaşlarının (Üstün ÜÜ., Gümüşgül O., Işık U., Demirel M., Harmandar Demirel D., 2016) Beden eğitimi ve spor yüksekokulu öğrencilerine yapmış oldukları araştırmasında; genişlik alt boyutunda cinsiyetler arasında istatistiksel olarak anlamlı bir farklılık tespit etmiştir. $\mathrm{Bu}$ araştırma bizim bulgularımızla paralellik göstermemektedir. Bu durumun spor bilimleri fakültelerinin ders müfredatlarının benzerlik göstermesi ile öğrencilerin kamu sektörü ve özel sektördeki iş tercihleri ve iş imkânlarının farklılık göstermemesinden, kaynaklanabileceği düşünülmektedir.

Katılımcıların zaman yönetimi davranışlarının cinsiyete göre karşılaştırılması incelendiğinde;

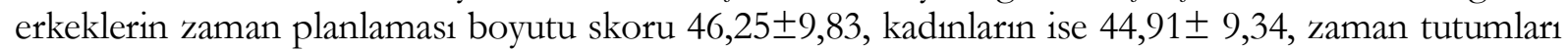

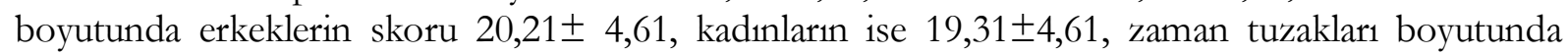

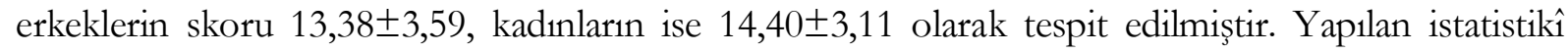
analizler sonucunda zaman tutumları boyutu ve zaman tuzakları boyutunda anlamlı farklılık tespit edilmiştir. Literatür incelendiğinde Karaoğlu (2015) tarafından Beden Eğitimi Spor Yüksekokulu öğrencilerine yapılan çalışmada; cinsiyetlerine göre zaman yönetimi davranışı alt boyutlarından aldıkları puan ortalamalarını erkek öğrencilerin zaman planlaması alt boyutu 34, kadın öğrencilerin 34 , zaman tutumları alt boyutu erkek öğrencilerin 24, kadın öğrencilerin 23 , zaman tuzakları alt boyutu erkek öğrencilerin 15, kadın öğrencilerin 14 olarak tespit edilmiştir. Öğrencilerin zaman yönetimi davranışı envanterinin zaman planlama, zaman tutumları ve zaman tuzakları alt 
Dallı, M., \& Pekel, A. (2017). Spor Bilimleri Fakültesinde öğrenim gören öğrencilerin gelecek zaman alg1 düzeyleri ile zaman yönetimi davranışlarının bazı değişkenlere göre değerlendirilmesi. Journal of Human Sciences, 14(2), 14201434. doi:10.14687/ihs.v14i2.4447

boyutlarından aldıkları puan ortalamaları cinsiyetlere göre incelendiğinde istatistiksel olarak anlamlı bir farklılık tespit edilmemiştir.Bu çalışma bulgularımızla benzerlik göstermemektedir.Alay (2000) ve Demirtaş ve Özer(2007)yaptıkları araştırmada zaman planlama becerilerinde kız öğrencilerin, erkek öğrencilerden daha başarılı olduklarını rapor etmiştir.Yapılan bu çalışmada ise zaman planlama boyutunda kız öğrenciler erkek öğrencilerden daha düşük puan almıstır. Başka bir çalısmada ise Gümüşgül (2013) Avrupa Birliği’ne üye ülkelerde ve Türkiye'de öğrenim gören üniversite öğrencilerinin zaman yönetimi anlayışlarının farklı değisskenler açısından incelenmesi üzerine yapmış olduğu çalışmasında; öğrencilerin zaman yönetimi davranışı alt boyutlarından; zaman tutumları ve zaman tuzakları boyutlarında istatistiksel olarak anlamlı farklılık tespit etmiştir. $\mathrm{Bu}$ araştırma çalışmamızın bulguları ile örtüşmektedir. Bu durumun erkek öğrencilerin farklı spor branşlarında kızlara oranla daha etkin olmaları, başarılı olmakistemeleri ve ideallerini gerçekleştirmek adına kararlı adımlarla ilerlemek istediklerinden kaynaklandığı düşünülmektedir.

Katılımcıların yaş değişkenine göre gelecek zaman alg1 düzeyleri incelendiğinde; bağlllık

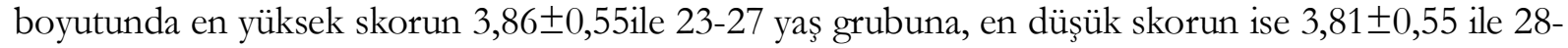

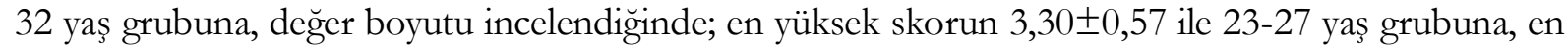

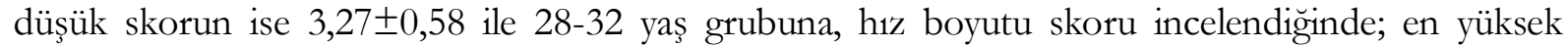

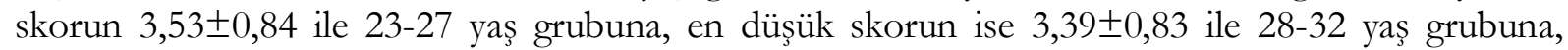

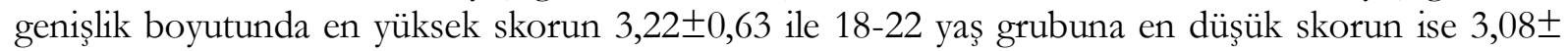
0,75 ile 28-32 yaş grubuna ait olduğu görülmektedir. Yapılan istatistiksel analiz sonucunda anlamlı farklılık tespit edilmemiştir.Literatür incelendiğinde Üstün ve arkadaşları (2016) tarafindan Beden Eğitimi ve Spor Yüksekokulu öğrencilerine yapılan araştırmada; katılımcıların yaşlarına göre gelecek zaman alg1sı alt boyutları anlamlı bir farklilık göstermemiştir. Bireyler ve öğrenciler spor yoluyla yarışma, işbirliği, disiplinli olma, kurallara uyma, hedefler koyma gibi davranışları öğrenmektedir (Loy JM., 1969).Bu durumun spor ile disipline olan farklı yaş grubundaki öğrencilerin gelecek planları ve algılarının farklılık göstermemesinden kaynaklandığı düşünülmektedir.

Katılımcıların yaş değişkenine göre zaman yönetimi davranışları incelendiğinde; Zaman

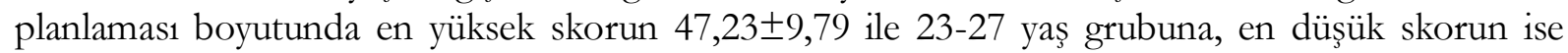

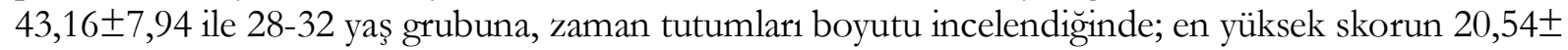

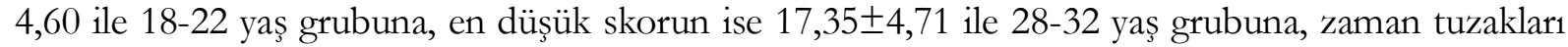

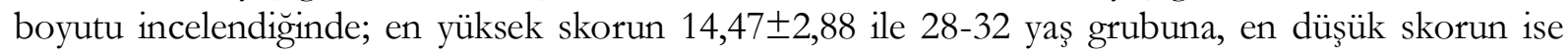
13,39 3,61 ile 23-27 yaş grubuna ait olduğu görülmektedir. Yapılan istatistiksel analiz sonucunda zaman planlaması, zaman tutumları ve zaman tuzakları boyutunda anlamlı farklılık tespit edilmiştir. Literatür incelendiğinde; Karaoğlu (2015) tarafindan Beden Eğitimi ve Spor Yüksekokulu öğrencilerine yönelik yapılan araştırmada; yaşlarına göre zaman planlaması alt boyutunda en yüksek skorun 35 ile 18-20 yaş grubu ve 24 ve üstü yaş 56 grubu öğrencilerinin, en düşük skorun ise 34 ile 21-23 yaş grubu öğrencilerinin aldığını tespit edilmiştir. Zaman tutumları alt boyutundan en yüksek skorun 24 ile 18-20 yaş grubu ve 24 ve üstü yaş grubu öğrencilerinin, en düşük skorun ise 23 ile 21 23 yaş grubu öğrencilerinin aldığını tespit etmiştir.Zaman tuzakları alt boyutundan en yüksek skorun 15 ile 18-20 yaş grubu ve 21-23 yaş grubu öğrencilerinin, en düşük skorun ise 14 ile 24 yaş ve üzeri yaş grubu öğrencilerinin aldığını tespit etmiştir. Ayrıca öğrencilerin zaman yönetimi envanterinin zaman planlama, zaman tutumları ve zaman tuzakları alt boyutlarından aldıkları puan ortalamaları arasında istatistiksel olarak anlamlı bir farklılık olmadığını tespit etmiştir. İşcan (2008) PamukkaleÜniversitesi öğrencileri üzerine yaptı̆̆1 araştırmada; zaman Yönetimi Becerilerinin Akademik Başarıları Üzerindeki Etkisi üzerine yaptığı çalışmasında; 25 yaş üstü üniversite öğrencilerinin 21 yaş altı ve 21-25 yaş arası üniversite öğrencilerine oranla daha etkili zaman yönetimi becerilerine sahip olduğunu tespit etmiştir. Ayrıca zaman yönetimi alt boyutları olan zaman planlama ve zaman tuzaklarında istatistiksel olarak anlamlı farkllık olmadığını, öğrencilerinin zaman tutumları ile yaşları arasında ise istatistiksel olarak anlamlı farklilık olduğunu tespit etmiştir.Uğur (2000) zamanı verimli kullanma isteğinin çoğunlukla yetişkin insanlarda görülen bir davranış biçimi olduğunu belirtmektedir.Bu açıklama bizim bulgularımızla ters düşmektedir. $\mathrm{Bu}$ 
Dallı, M., \& Pekel, A. (2017). Spor Bilimleri Fakültesinde öğrenim gören öğrencilerin gelecek zaman alg1 düzeyleri ile zaman yönetimi davranışlarının bazı değişkenlere göre değerlendirilmesi. Journal of Human Sciences, 14(2), 1420 1434. doi:10.14687/ihs.v14i2.4447

durumun katılımcıların genelinin spora erken yaşlarda başlayarak zamanlarını sportif başarıya özgü düzenlemek istemeleri, üniversite eğitimi ile hedeflerinin farklılaşarak sportif başarının yanı sıra akademik olarak gelişim göstermek ve iş hayatına yönelik hedefler belirlemelerinden ayrıca yaşın ilerlemesiyle ortaya çıkan olumsuzluklardan daha fazla etkilenmelerinden kaynaklandığ1 düşünülmektedir. Katılımcıların üniversite değisskenine göre gelecek zaman alg1 düzeyleri

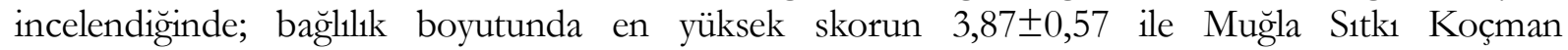
Üniversitesi, en düşük skorun ise 3,81 $\pm 0,54$ ile Gazi Üniversitesi’ne, değer boyutu incelendiğinde; en yüksek skorun 3,31 $\pm 0,58$ ile Muğla Sttk1 Koçman Üniversitesi, en düşük skorun ise 3,26 $\pm 0,52$ ile

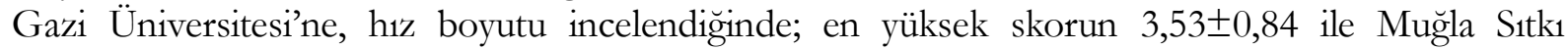

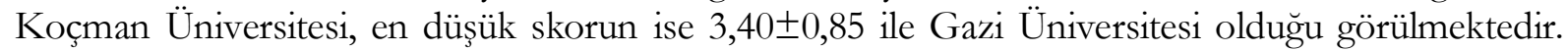
Ayrica yapılan istatistiksel analiz sonucunda anlamlı farklillk tespit edilmemiştir.Literatür incelendiğinde üniversite ve gelecek zaman algisı arasındaki ilişkiyi inceleyen herhangi bir çalışmaya rastlanılmamıştır.Bu durumun öğrencilerin yaşamış oldukları sosyal çevre, yaşam standartları, genel öz yeterlilikleri, kendilerini gerçekleştirme düzeyleri ve geleceğe bakış acılarından kaynaklandığ1 düşünülmektedir.

Katılımcıların üniversite değişkenine göre zaman yönetimi davranışları incelendiğinde; zaman planlaması boyutunda en yüksek skorun 49,40 $\pm 10,43$ ile Muğla S1tk1 Koçman Üniversitesi, en düşük skorun ise 43,59 $\pm 8,60$ ile Selçuk Üniversitesi'ne, zaman tutumları boyutu incelendiğinde; en

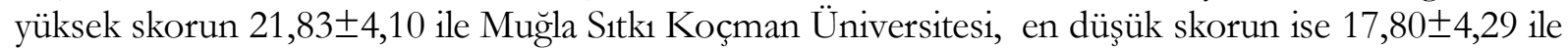
Selçuk Üniversitesi'ne, zaman tuzakları boyutu incelendiğinde; en yüksek skorun 14,76 $\pm 3,05$ ile Selçuk Üniversitesi'ne, en düşük skorun ise 12,71 $\pm 3,54$ ile Gazi Üniversitesi’ne ait olduğu görülmektedir. Ayrıca yapılan istatistiksel analiz sonucunda zaman planlaması, zaman tutumları ve zaman tuzakları boyutunda anlamlı farklılık tespit edilmiştir.Literatür incelendiğinde; üniversite ve zaman yönetimi davranışı alt boyutları arasındaki ilişkiyi inceleyen herhangi bir çalşsmaya rastlanılmamıştır.Bu durumun üniversitelerin sunmuş olduğu imkânların farklılık göstermesi ve üniversitelerin vizyon ve misyonunun öğrenciler üzerinde etkili olmasından kaynaklandığ1 düşünülmektedir.

Katılımcıların bölüm değişkenine göre gelecek zaman alg1 düzeyleri incelendiğinde; bağlllık

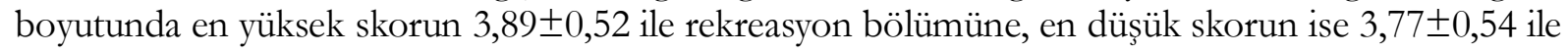
spor yöneticiliği bölümüne, değer boyutu incelendiğinde; en yüksek skorun $3,36 \pm 0,58$ ile beden eğitimi ve spor öğretmenliği bölümüne, en düşük skorun ise $3,20 \pm 0,53$ ile spor yöneticiliği

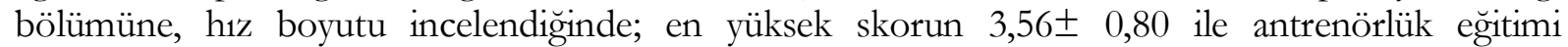
bölümüne, en düşük skorun ise $3,43 \pm 0,88$ ile spor yöneticiliği bölümüne, genişlik boyutunda en

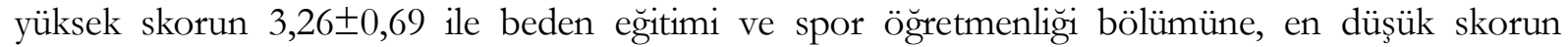
3,13 $\pm 0,62$ ile antrenörlük eğitimi bölümüne ait olduğu görülmektedir. Ayrıca yapılan istatistiksel analiz sonucunda değer boyutunda anlamlı farklılık tespit edilmiştir. Literatür incelendiğinde; Üstün ve arkadaşları (2016) tarafindan Beden Eğitimi ve Spor Yüksekokulu öğrencilerine yönelik yapılan araştırmada; öğrencilerin öğrenim gördükleri bölümlere göre gelecek zaman algıları, rekreasyon bölümü öğrencilerinin lehinde genişlik alt boyutunda anlamlı farklılık tespit edilmiştir. Yapılan bu çalışmada ise beden eğitimi ve spor öğretmenliği bölümü öğrencilerinin lehinde değer alt boyutunda istatistiksel olarak anlamlı farkllık tespit edilmiştir.Bu durumun beden eğitimi ve spor öğretmenliği bölümü öğrencilerin içinde bulunulan zamanın gereklerine göstermiş olduğu özen ve uzak gelecekteki hedeflere verdiği önemden kaynaklandığı düşünülmektedir.

Katılımcıların bölüm değişkenine göre zaman yönetimi davranışları incelendiğinde; zaman planlaması boyutunda en yüksek skorun $48,50 \pm 9,82$ ile antrenörlük eğitimi bölümü, en düşük skorun ise 43,99 $\pm 8,36$ ile beden eğitimi ve spor öğretmenliği bölümüne, zaman tutumları boyutu

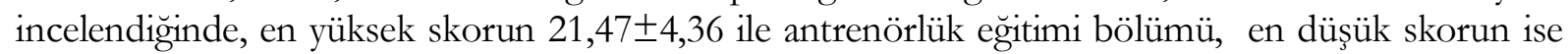
$18,72 \pm 4,58$ ile beden eğitimi ve spor öğretmenliği bölümüne, zaman tuzakları boyutu incelendiğinde; en yüksek skorun 14,21 \pm 3 ,41 ile spor yöneticiliği bölümüne, en düşük skorun ise 13,42 23,56 ile antrenörlük eğitimi bölümüne ait olduğu görülmektedir. Ayrıca yapılan istatistiksel 
Dallı, M., \& Pekel, A. (2017). Spor Bilimleri Fakültesinde öğrenim gören öğrencilerin gelecek zaman alg1 düzeyleri ile zaman yönetimi davranışlarının bazı değişkenlere göre değerlendirilmesi. Journal of Human Sciences, 14(2), 14201434. doi:10.14687/ihs.v14i2.4447

analiz sonucunda zaman planlaması ve zaman tutumları boyutunda anlamlı farklılık tespit edilmiştir. Literatür incelendiğinde; Karaoğlu (20015) tarafindan yapılan çalısmada; Beden Eğitimi ve Spor Yüksekokulu öğrencilerinin bölümlerine göre zaman yönetimi envanteri alt boyutlarından aldıkları puan ortalamaları zaman planlaması alt boyutunda en yüksek skorun 36 ile antrenörlük eğitimi bölümü öğrencilerine; en düşük skorun ise 33 ile yöneticilik bölümü öğrencilerine ait olduğunu tespit edilmiştir. Ayrıca yapılan istatistiksel işlem sonucunda antrenörlük eğitimi ile spor yöneticiliği bölümlerinde öğrenim gören öğrencilerin zaman planlama alt boyutunda antrenörlük eğitimi yönünde anlamlı farklılık tespit edilmiştir. Zaman tutumları alt boyutundan en yüksek skorun 25.5 ile spor yöneticiliği bölümüne, en düşük skorun ise 23 ile rekreasyon ve antrenörlük eğitimi bölümleri öğrencilerine ait olduğu görülmektedir. Yapılan istatistiksel işlem sonucunda beden eğitimi ve spor öğretmenliği ile spor yöneticiliği, antrenörlük eğitimi ile spor yöneticiliği ve spor yöneticiliği ile rekreasyon uzmanlığı bölümleri arasında spor yöneticiliği bölümü yönünde anlamlı farklılık tespit edilmiştir.Zaman tuzakları alt boyutunda en yüksek skorun 16 ile antrenörlük eğitimi öğrencilerine, en düşük skorun ise 13 ile yöneticilik bölümüne ait olduğunu raporlaştırmıştır.Ayrıca yapılan istatistiksel işlem sonucunda beden eğitimi ve spor öğretmenliği ile antrenörlük eğitimi eğitimi, antrenörlük eğitimi eğitimi ile spor yöneticiliği ve spor yöneticiliği ile rekreasyon uzmanlı̆̆1 bölümleri arasında anlamlı farklılık tespit etmiştir.Andıç (2009) üniversite öğrencilerinin zaman yönetimi becerileri ile akademik başarıları arasındaki ilişkisi üzerine yapmış olduğu çalışmasında; öğrencilerin okudukları bölümler ile zaman yönetimi becerileri arasında istatistiksel olarak anlamlı bir farklılı̆̆ın olmadığını tespit etmiştir. Başka bir çalışmada ise Erdem, Pirinçci,ve Dikmetaş (2003) üniversite öğrencilerinin zaman yönetimi davranışları ve bu davranışların akademik başarı ile ilişkisi üzerine yapmış oldukları çalışmada; bölümler ile zaman yönetimi becerileri arasında istatistiksel olarak anlamlı farklilığın olduğunu tespit etmişlerdir.

Bu durumun öğrencilerin yaşam standartlarının ve hayata bakış açılarının farklılık göstermesi, bölümlerin ders müfredatındaki farklılıklar ve öğrencilerin eğitim görmüş oldukları bölümlere göre gelecek ile ilgili planlara odaklanmadaki farklılıklardan kaynaklandığı düşünülmektedir.

Sonuç olarak; gelecek zaman algısının bölüm değişkeni ile zaman yönetimi davranışının cinsiyet, yaş, üniversite ve bölüm değişkenleri ile ilişkili olduğu tespit edilmiştir. Bu durumun spor bilimleri fakültelerinde öğrenim gören öğrencilerin kendilerini gerçekleştirme düzeyleri, almış oldukları teorik ve uygulama derslerinin farkllığ1, öğrencilerin sorumluluklarına olan bağlllı̆̆1, yaşanılan iç ve diş çevreninin sosyolojik yapısı ve karşılaşılan firsatların farklılığından kaynaklandığı düşünülmektedir.

\section{ÖNERILLER}

1. Farkl1 fakültelerde öğrenim gören öğrencilerin gelecek zaman alg1 düzeyleri ile zaman yönetimi davranışları arasındaki ilişki değerlendirilebilir.

2. Bu çalışmadan yola çıkarak farklı spor branşlarındaki oyuncuların gelecek zaman algı düzeyleri ile zaman yönetimi davranışları arasındaki ilişki değerlendirilebilir.

3. Spor işletmelerinde görevli spor yöneticilerinin gelecek zaman alg1 düzeyleri ile zaman yönetimi davranışları arasındaki ilişki değerlendirilebilir.

4. Bu çalışmadan yola çıkarak farklı değişkenler ile gelecek zaman algisı ve zaman yönetimi davranışları arasındaki ilişki değerlendirilebilir.

\section{KAYNAKÇA}

Avcı, S. (2008). Öğretmen Adaylarının, Gelecek Zaman Algıları, Akademik Alandaki Arzularını Erteleme Konusundaki İsteklilikleri, Algılanan Araçsallıkları, Sosyo- Ekonomik Düzeyleri Ve Akademik Başarıları Arasındaki Açıklayıcı Ve Yordayıcı İlişkiler Örüntüsü. Yayımlanmamış Doktora Tezi. Yıldız Teknik Üniversitesi. Sosyal Bilimler Enstitüsü.

Avc1, S., Erden, M. (2009). Gelecek Zaman Alg1sı Ölçeği’nin Türkçe Formunun Geçerlik Ve Güvenirlik Çalışması. Çukurova Üniversitesi Eğitim Fakültesi Dergisi, 3(37), 1-12. 
Dallı, M., \& Pekel, A. (2017). Spor Bilimleri Fakültesinde öğrenim gören öğrencilerin gelecek zaman alg1 düzeyleri ile zaman yönetimi davranışlarının bazı değişkenlere göre değerlendirilmesi. Journal of Human Sciences, 14(2), 1420 1434. doi: $10.14687 /$ ihs.v14i2.4447

Britton, B. K, Tesser, A. Effects of Time Management Practices on College Grades, Journal Of Educational Psychology, 1991: 405-410.

Avc1, S., Erden, M. 2013.Gelecek zaman alg1s1 ve akademik alanda arzularin ertelenmesinin öğretmen adaylarının akademik başarıları üzerindeki etkisi. Ahi Evran Üniversitesi Kırşehir Eğitim Fakültesi Dergisi, 14(1), 389-406.

Alay, S. Relationship between Time Management and Academic Achievement of Selected University Students, Orta Doğu Teknik Üniversitesi Sosyal Bilimler Enstitüsü, Ankara, 2000: 11-70.

Alay, S., Koçak, S. Validityand Reliability of Time Management Questionnaire, Hacettepe Üniversitesi Eğitim Fakültesi Dergisi 2002; 9-13.

Andıç, H. Üniversite Öğrencilerinin Zaman Yönetimi Becerileri İle Akademik Başarıları Arasındaki İlişki, Yüksek Lisans Tezi, Sosyal Bilimler Enstitüsü, Afyonkarahisar, 2009: 65.

Demirtas, H., Özer, N. Öğretmen Adaylarının Zaman Yönetimi Becerileri ile Akademik Başarısı Arasındaki ilişkisi, Eğitimde Politika Analizleri ve Stratejik Araştırmalar Dergisi, 2007; 3447.

Erdem, R, Pirinçci, E., Dikmetaş, E. Üniversite Öğrencilerinin Zaman Yönetimi Davranışları ve Akademik Başarı ile İlişkisi, 2003: 167-177.

Erdul, G. Üniversite Öğrencilerinin Zaman Yönetimi Becerileri ile Kayg1 Düzeyleri Arasındaki İlişki, Uludağ Üniversitesi Sosyal Bilimler Enstitüsü, Bursa, 2005: 8-44.

Gümüşü̈l, O. Avrupa Birliği’ne Üye Ülkelerde ve Türkiye'de Öğrenim Gören Üniversite Öğrencilerinin Zaman Yönetimi Anlayışlarının Farklı Değişkenler Açısından İncelenmesi, Yüksek lisans tezi, Kütahya, 2013: 71-73.

Gürbüz, M., Aydın, A. H., Zaman Kavramı ve Yönetimi Kahramanmaraş Sütçü İmam Üniversitesi Sosyal Bilimler Dergisi 2012; 1-20.

Gözel, E., Halat, E. İlköğretim Okulu Öğretmenleri ve Zaman Yönetimi, Pamukkale Üniversitesi Sosyal Bilimler Enstitüsü Dergisi 2010; 73-89.

Husman, J.E., Shell, D.F. (1996). Beliefs and Perceptions aboutThe Future: A Conceptualization and Measurement of Future Time Perspective. The XXVI International Congress of Psychology Sunulmuş Bildiri, Montreal, Canada

İşcan, S. Pamukkale Üniversitesi Öğrencilerinin Zaman Yönetimi Becerilerinin Akademik Başarıları Üzerindeki Etkisi, Yüksek Lisans Tezi, Pamukkale Üniversitesi Sosyal Bilimler Enstitüsü, Denizli, 2008: 9-74.

Karaoğlu, B. Erciyes Üniversitesi Beden Eğitimi Spor Yüksekokulu Öğrencilerinin Zaman Yönetimi Davranışlarının Farklı Değişkenler Açısından İncelenmesi. Yüksek Lisans Tezi, Beden Eğitimi Ve Spor Anabilim Dalı, Sağlık Bilimleri Enstitüsü, Erciyes Üniversitesi. Kayseri 2015: 88.

Latif, H., Fidan, F., Uçkun, G. Üniversite Gençliğinin Zaman Yönetimi Bilinci ve Eğilimleri, Sakarya Üniversitesi Örneği, İstanbul Üniversitesi İşletme İktisadi Enstitüsü Yönetim Dergisi 2005; 41-51.

Loy, J. M., Mc Pherson, B. D, Kenyon, G. (1969). Sportand Social Systems. California: AddisonWesley Publishing Company

Nuttin, J., Lens, W. (1985). Future Time Perspective and Motivation: Theory and Research Method. Belgium: Lawrence Erlbaum Associates.

Sabuncuoğlu, Z., Tüz, M. Örgütsel Psikoloji, Alfa Yayınları, Bursa, 2003: 28-281.

Safran, M., Şimşek, A. (2009), Çocuklarda Zaman Algısının Gelişimi, Uluslararası Sosyal Araştırmalar Dergisi,2(6), 542-548.

Simons, J., Vansteenkiste, M., Lens, W., Lacante, M. (2004). Placing motivation and future time perspective theory in a temporal perspective. Educational Psychology Review, 16(2), 121139. 
Dallı, M., \& Pekel, A. (2017). Spor Bilimleri Fakültesinde öğrenim gören öğrencilerin gelecek zaman alg1 düzeyleri ile zaman yönetimi davranışlarının bazı değişkenlere göre değerlendirilmesi. Journal of Human Sciences, 14(2), 14201434. doi:10.14687/ihs.v14i2.4447

Uğur, A. (2000). Çalışma Hayatında Zaman Yönetimi, Anahtar Dergisi, MPM Yayınları. Yıl 12, Sayı.143, 18-22.

Uyanıker, E. A. Yönetici Hemşirelerin Genel Öz Yeterlilik İnancı İle Zaman Yönetimi Arasındaki İlişki, Yüksek Lisans Tezi, Sağlık Bilimleri Enstitüsü, İstanbul, 2014: 111.

Üstün, Ü. Ü., Gümüşgül O., Işık U., Demirel M., Harmandar Demirel D., Gelecek Zaman Alg1sı: Beden Eğitimi ve Spor Yüksekokulu Öğrencilerine Yönelik Bir Çalışma, İÜ Spor Bilimleri Dergisi 2016, Cilt (Vol) 6, Say1 (No) 1 1303-1414.

\section{Extended English Abstract}

\section{Introduction}

In societies, a common time perception gained independently by the people is needed for effective handling of works since people organize their daily lives depending on time (Safran M., Şimşek A., 2009). Temporal distance of targets set by each individual for the future is different from one another. While some people make plans for ten years later, some make plans just for six months later (Nuttin J., Lens W., 1985). The perception of future is defined as the impact of one person's expectations and targets for near or distant future on the current actions(Simons J., Vansteenkiste M., Lens W., Lacante M., 2004, Avc1 S., Erden M., 2013). Behaviours displayed by individuals in their daily lives aim at achieving a certain objective, and these targets may aim at meeting instant needs or be related to an expectation for the near future or be related to a dream to be fulfilled in a distant future like five or ten years (Avc1 S., 2008).

The ability to control time depends on the analysis of how the time is used. Giving a right decision on valuing the time is more important than performing an action efficiently since it is necessary to perform the right action at the right time. On the other hand, adding an intellectual dimension into the actions or activities performed and performing them with effort, patience and enthusiasm are important, as well (Latif H, Fidan F, Uçkun G., 2005). Failure in controlling the time is the failure in controlling the life. At this point, needs of people to figure out how they can control the time they have more efficiently and effectively led to the emergence of a new concept called "time management" (Sabuncuoğlu Z., Tüz M., 2003). Time management is a technique of developing a personal performance which is considered to be vital for achieving targets, checking the actions performed and increasing motivation (Gürbüz M., Aydın AH., 2012).

\section{Method}

Population of the research consisted of Gazi, Selçuk and Muğla Sitk1 Koçman Universities while its sample consisted of the students $(n=747)$ studying in the departments of coaching teaching, physical education and sports teaching, recreation expertise and sport management in the faculties of sports sciences affiliated to these universities. Students were randomly selected and participated in the study voluntarily. "Future time perspective scale" which consists of 27 items and was developed by Husman and Shell (1996) and adapted into Turkish by Avc1 and Erden (2009) was used as the data collection tool. The scale has four subscales which are commitment (12 items), value (7 items), width (5 items) and speed (3 items). It is scored as a 5 -point Likert type scale from "strongly agree $=5$ " to "strongly disagree $=1$ ". Reliability coefficients of the scale are high while the coefficients of the commitment, value, speed and width subscales are found to be $0.82,0.72,0.72$ and 0.74 , respectively. The other scale used as the data collection tool is the "time management behaviour scale" which consists of 27 items and was developed by Britton and Tesser (1991) and adapted into Turkish by Alay and Koçak (2002). The subscales of this scale are time planning (16 items), time attitudes ( 7 items) and time traps (4 items). It is scored as a 5 -point Likert type scale from "always $=5$ " to "never $=1$ ". Reliability coefficient of the scale is 0.80 , which shows that the 
Dallı, M., \& Pekel, A. (2017). Spor Bilimleri Fakültesinde öğrenim gören öğrencilerin gelecek zaman alg1 düzeyleri ile zaman yönetimi davranışlarının bazı değişkenlere göre değerlendirilmesi. Journal of Human Sciences, 14(2), 14201434. doi:10.14687/ihs.v14i2.4447

scale is highly reliable. Reliability coefficients of the subscales of time planning, time attitudes and time traps are $0.88,0.66$ and 0.47 , respectively.

In statistical terms, parametric and non-parametric distributions of the data were examined. Parametric, non-parametric curves and skewness-kurtosis values reveal that data displayed parametric distribution. Also, Independent Sample T Test was used for the comparison by sex while One Way Anova Test was used for the comparison by age, university and department.

\section{Findings}

It was determined that participants who joined the study have a mean of 3,43 $\pm 0,66$ in commitment sub dimension score of Future Time Perception scale, of 3,29 $\pm 0,56$ in value sub dimension, of $3,47 \pm 0,85$ in speed sub dimension, of $3,17 \pm 0,67$ in width sub dimension, of $3,89 \pm 0,48$ in total score of Future Time Perception, as it was looked at the sub dimension average scores of Time Scheduling Scale, they have a mean of 45,75 $\pm 9,67$ in Time Scheduling Dimension,

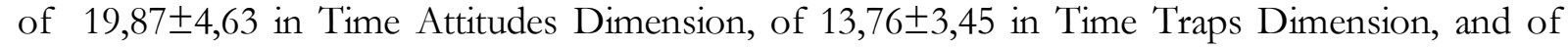
$79,38 \pm 12,81$ in total score of Time Management .

It was confirmed that score of male commitment dimension is $3,45 \pm 0,68$, of female commitment dimension is $3,40 \pm 0,64$, male score of value dimension is $3,29 \pm 0,57$, female score is $3,28 \pm 0,54$, male score of speed dimension is $3,45 \pm 0,84$, female score is $3,52 \pm 0,85$, male score of width score is $3,16 \pm 0,68$, female score is $3,19 \pm 0,67$. No statistically significant difference was found as a result of statistical analysis $(\mathrm{p}>0,05)$

It was determined that the score of time scheduling dimension of men is $46,25 \pm 9,83$, of women is $44,91 \pm 9,34$, the score of time attitudes dimension of men is $20,21 \pm 4,61$, of women is $19,31 \pm 4,61$, the score of time traps dimension of men is $13,38 \pm 3,59$, of women is $14,40 \pm 3,11$. As a result of the statistical analyzes made, there was a significant difference in time attitudes dimension and time traps dimension $(\mathrm{p}<0,05)$.

When the level of perception of future time was examined according to age variable of participants; it was seen that the highest score in commitment dimension belongs to 23-27 age group with $3.86 \pm 0.55$ and the lowest score belongs to 28-32 age group with $3.81 \pm 0.55$, when value dimension is examined, the highest score belongs to 23-27 age group with $3.30 \pm 0.57$, the lowest score belongs to 28-32 age group with $3.27 \pm 0.58$, when speed dimension was examined the highest score belongs to 23-27 age group with $3.53 \pm 0.84$, the lowest score belongs to 28-32 age group with $3.39 \pm 0.83$ and the highest score of width dimension belongs to 18-22 age group with $3.22 \pm 0.63$ and the lowest score belongs to $28-32$ age group with 3,08 $\pm 0,75$. No statistically significant difference was found as a result of the statistical analysis performed $(p>0,05)$

As time management behaviors were looked at according to age of participants, the highest score of time scheduling dimension belongs to $23-27$ age group with 47,23 $\pm 9,79$, the lowest score belongs to 28-32 age group with 43,16 $\pm 7,94$, as time attitudes dimension was examined, the highest score belongs to 18-22 age group with 20,54 \pm 4,60, the lowest score belongs to 28-32 age group with $17,35 \pm 4,71$, as time traps attitude was examined the highest score belongs to 28-32 age group with $14,47 \pm 2,88$, the lowest score belongs to $23-27$ age group with 13,39 $\pm 3,61$. As a result of statistical analysis, meaningful differences were found in time scheduling, time attitudes and time traps dimensions. $(\mathrm{p}<0,05)$.

When the perceived levels of future participants' perceptions were examined according to university variables, it was seen that the highest score in commitment dimension belongs to Muğla Sitk1 Koçman University with 3,87 \pm 0,57 and the lowest score belongs to Gazi University with $3,81 \pm 0,54$. When the value dimension was examined, it was seen that the highest score belongs to Muğla Sitk1 Koçman University with 3,31 \pm 0,58 and the lowest score belongs to Gazi University with 3,26 $\pm 0,52$. When Speed Dimension was examined, it was seen that the highest score is 3,53 \pm 0,84 with Muğla Sitk1 Koçman University and the lowest score is with Gazi University with 3,40 $\pm 0,85$. No statistically significant difference was found in the statistical analysis. 
Dallı, M., \& Pekel, A. (2017). Spor Bilimleri Fakültesinde öğrenim gören öğrencilerin gelecek zaman alg1 düzeyleri ile zaman yönetimi davranışlarının bazı değişkenlere göre değerlendirilmesi. Journal of Human Sciences, 14(2), 14201434. doi:10.14687/ihs.v14i2.4447

When the participants' time management behaviors were examined according to university variables, it was seen that the highest score in the time scheduling dimension belongs to Muğla Sitk1 Koçman University with 49,40 $\pm 10,43$ and the lowest score belongs to Selçuk University with $43,59 \pm 8,60$. When the time attitudes dimension was examined, it was seen that the highest score belongs to Muğla Sttkı Koçman University with 21,83 \pm 4,10 and the lowest score belongs to Selçuk University with $17,80 \pm 4,29$. When time traps dimensions were examined, it was seen that the highest score belongs to Selcuk University with 14,76 $\pm 3,05$ and the lowest score belongs to Gazi University with $12,71 \pm 3,54$. As a result of statistical analysis, significant differences were found in time scheduling, time attitudes and time traps dimensions $(\mathrm{p}<0.001)$.

When the perception levels of future time of participants according to departmental variables were examined, it was seen that the highest score in commitment dimension belongs to the department of recreation with 3,89 $\pm 0,52$ and the lowest score belongs to the department of sports administration with $3,77 \pm 0,54$. When the value dimension was examined, it was seen that the highest score belongs to the department of physical education and sports teaching with $3,36 \pm 0,58$ and the lowest score belongs to the department of sports administration with $3,20 \pm 0,53$. When Speed Dimension was examined, it was seen that the highest score is 3,56 $\pm 0,80$ with the department of coaching education and the lowest score belongs with the department of sports administration with $3,43 \pm 0,88$. The highest score in the width dimension is $3,26 \pm 0,69$ for the department of physical education and sport teaching, the lowest score is $3,13 \pm 0,62$ for the coaching education department. As a result of the statistical analysis, significant difference was found in value dimension $(\mathrm{p}<0,05)$.

When time management behaviors according to departmental variables of participants were examined, it was seen that the highest score in the time scheduling dimension belongs to the department of coach training with $48.50 \pm 9.82$ and the lowest score to department of physical education and sports teaching with $43.99 \pm 8.36$. When time attitudes dimension was examined the highest score belongs to department of coach training with $21,47 \pm 4,36$, the lowest score belongs to department of (?) education with 18,72 $\pm 4,58$. As time traps dimension was examined It was seen that the highest score belongs to the department of sports administration with 14,21 $\pm 3,41$ and the lowest score belongs to the department of coach training education with $13,42 \pm 3,56$. As a result of the statistical analysis, meaningful difference was found in time scheduling and time attitudes dimension $(\mathrm{p}<0.001)$.

\section{Conclusion}

As a conclusion, it was found out that future time perception is related to the variable of department while time management behaviour is associated with the variables of sex, age, university and department. It is thought that this finding has resulted from self-realization levels of the students studying in the Faculties of Sports Sciences, differences in the theory and practice courses they have received, commitments of the students to their responsibilities, sociological structure of the internal and external environments in which students live and differences in opportunities that the students encounter.

\section{Recommendations}

1. The relations between future time perception levels and time management behaviours of the students studying in different faculties can be examined.

2. Based on this study, the relations between the future time perception levels and time management behaviours of performers of different branches of sports can be examined.

3. The relations between the future time perception levels and time management behaviours of the sport managers working in the sport enterprises can be examined.

4. Based on this study, the relations between the future time perception and time management behaviours and various variables can be examined. 